\title{
Impact of fuel costs on high-latitude subsistence activities
}

\author{
$\underline{\text { Todd Brinkman }}^{1}$, Karonhiakta'tie B. Maracle $^{2}$, James Kelly $^{2}$, Michelle Vandyke $^{2}$, Andrew Firmin $^{2}$ and Anna Springsteen ${ }^{3}$
}

\begin{abstract}
Most rural residents in Arctic communities rely on motorized transportation to hunt, fish, trap, and gather subsistence resources. Although these technologies have created advantages, one significant disadvantage is that peoples' ability to meet their nutritional and cultural needs now depends on consistent opportunities for wage employment and availability of affordable fuel. Recent qualitative research suggested that rising fuel prices have disrupted subsistence lifestyles in the Arctic. Our objectives were to collaborate with subsistence users in rural Alaskan communities to quantify how rising fuel costs have impacted subsistence activities and explore ways local residents may adapt to the trajectory of change. We conducted interviews with 178 subsistence harvesters in 8 communities. During the last 10 years, $81 \%$ of the harvesters reduced the distance they traveled for subsistence and $89 \%$ reduced the number of subsistence trips they took because of gasoline costs. During the last 10 years, the median distance traveled to perform subsistence decreased by $60 \%$, and the median annual number of trips taken to perform subsistence decreased by $75 \%$. The change in subsistence activity was similar across and within communities. Eighty-five percent of the people interviewed reported that they were making sacrifices with serious consequences, such as putting off paying monthly bills, to buy gasoline for subsistence activities. To adapt to high gasoline prices, most participants said that they are using more efficient modes of transportation (69\%), followed by more sharing of gasoline costs with family and friends (37\%), and conducting more multipurpose subsistence trips (20\%). With subsistence practices being critical to food security and cultural identity in the Arctic, our results suggest that unaffordable fuel has threatened social resilience. Because global markets drive gasoline prices, we suggest that future research focus on the effectiveness of adaptation options that build resilience into subsistence systems.
\end{abstract}

Key Words: adaptation; Alaska; gasoline; interviews; social resilience; subsistence

\section{INTRODUCTION}

Fossil-fuel markets affect nearly all societies and nearly all environments that societies depend on. Identifying trends in the relationship between changes in fossil-fuel availability and societal response can foster planning for and adaptation to future social and economic conditions. Understanding this dynamic relationship may be particularly important when the availability of affordable fuel is linked to community well-being, e.g., cultural identity and food security. We investigated the tight linkage between affordable gasoline and subsistence activity in rural and remote communities in Arctic Alaska. Also, we identified recent adaptations of residents of these communities that aim to maintain the resilience of their social-ecological system.

We define social resilience as the ability of groups to cope with stresses caused by a change while maintaining essential characteristics of the system (Adger 2000, Chapin et al. 2009). The change we address is rising gasoline prices because of voracious global demand for a resource with a finite supply, and the threat is the decreasing capacity of rural communities to afford the gasoline required to maintain their subsistence system in its current form at its current level. Resilience depends on the degree to which the subsistence system can self-organize, learn, and adapt (Folke et al. 2002). We refer to adaptation as the actions of subsistence harvesters in response to unaffordable fuel. Clearly, the concepts of resilience and adaptation are interrelated. Both concepts have been extensively reviewed (Berkes and Folke 1998, Smit and Wandel 2006). Within the context of social-ecological systems in the Arctic, our contribution is a quantitative description of the increasingly common consequences of rising gasoline prices that weaken the resilience of subsistence livelihoods. We also document the frequency of locally identified strategies that may enhance resilience to an external threat common throughout the Arctic.

Subsistence, defined as customary and traditional uses of wild resources, is a major component the way of life in Arctic communities (Caulfield 1983, Nelson et al. 2008, Fall 2010, McNeeley and Shulski 2011). In rural Alaska, approximately $31 \%$ of caloric requirements come from subsistence foods, and annual harvest averages $143 \mathrm{~kg}$ per person (Fall 2010). In addition to food security, subsistence activities are essential to Native Alaskan culture (Lambden et al. 2007, and Smith et al. 2009). For example, many indigenous groups identify themselves based on their primary subsistence resources (e.g., "caribou people," Kofinas 1998). Given the significance of identity at times of rapid socioeconomic change (Kinzig et al. 2006), maintaining access to subsistence resources is crucial for social resilience.

Residents of rural Alaska are part of a mixed subsistence-cash economy. Households invest monetary earnings into efficient technologies such as motorized vehicles to facilitate harvest of wild resources for their own consumption, rather than for the commercial market. Since the middle of the 20th century, involvement in wage employment has increased so that residents can afford technological innovations that augment subsistence (Schroeder et al. 1987). For example, snowmobiles replaced dog teams for transportation in many rural communities in northern Alaska in the 1960s and 1970s (Francis 1969, Hall 1971, Osburn 1974). Time spent participating in the cash economy was offset by increased mobility with snowmobiles and a reduction in responsibilities associated with caring for a dog team.

Currently, most rural residents in Alaska communities rely on motorized boats, snowmobiles, four-wheelers, and other all-

${ }^{1}$ Institute of Arctic Biology, University of Alaska Fairbanks, ${ }^{2}$ Council of Athabascan Tribal Governments, ${ }^{3}$ Scenarios Network for Alaska and Arctic Planning, University of Alaska Fairbanks 
terrain vehicles (ATVs) to hunt, fish, trap, and gather subsistence resources. Although these technologies have created advantages such as increased harvest efficiency, one significant disadvantage is that peoples' ability to meet their nutritional and cultural needs now depends on consistent opportunities for wage employment and availability of affordable fuel. Because jobs are limited and fuel costs are disproportionately higher in remote areas of Alaska, this reliance has put rural communities in a vulnerable situation (Van Lanen et al. 2012). Communities in Alaska that are disconnected from the road network and seaports, i.e., remote rural communities, have some of the highest fuel costs and lowest per capita income levels in the United States (Alaska Community Database 2014). For example, during January 2012, average retail gasoline prices off the road system in Interior Alaska were $\$ 6.63$ per gallon (\$1.75/L; ADCCED 2012). The nationwide average at this time was $\$ 3.24$ per gallon $(\$ 0.86 / \mathrm{L}$; U.S. Energy Information Administration 2012). Increases in fuel costs in rural Alaska also have exceeded the U.S. average. Between November 2005, when record keeping began in rural Alaska, and January 2012, gasoline prices off the road system in Interior Alaska have increased by \$2.31 per gallon (\$0.61/L; ADCCED 2006, 2012), whereas the U. S. average increased by $\$ 0.95$ per gallon $(\$ 0.25 / L$; U.S. Energy Information Administration 2012). High fuel prices in remote rural communities of Alaska are a result of many factors including high transportation costs, limited and costly storage, small market size, and financing issues associated with holding large inventories (Szymoniak et al. 2010, ADCCED 2012). For example, the high fuel price of $\$ 10$ per gallon $(\$ 2.64 / \mathrm{L})$ in January 2012 in the remote community of Arctic Village, Alaska, is likely because fuel is transported by air, and there is limited competition among suppliers.

During the recent decade, rural communities have expressed concern that rising gasoline prices are having a significant impact on subsistence opportunities (Kofinas et al. 2010, McNeely and Shulski 2011, Moerlein and Carothers 2012, Van Lanen et al. 2012). The close connection between an active subsistence lifestyle and social resilience in rural Alaska warrants a rigorous analysis of the extent of this impact. We are unaware of previous efforts to quantify the extent that subsistence has been affected by gasoline costs. Quantifying the effect helps a broader audience understand the level of stress that unaffordable fuel places on rural Alaska communities and facilitates an opportunity for comparison with other studies (e.g., Heltberg et al. 2013) on social resilience related to food, fuel, and financial crises. Therefore, our objectives were to collaborate with subsistence users in several rural Alaskan communities to describe and quantify how rising fuel costs have impacted subsistence activities and to explore ways local residents might adapt to the trajectory of change. The remoteness and isolation of the communities we collaborated with created a unique opportunity to reduce the number of confounding factors affecting the association between fuel prices and subsistence. We believe that the ubiquity of reliance on both fossil fuels and subsistence resources throughout the Arctic fostered broad relevance and application of our findings.

\section{STUDY AREA}

Our research was conducted in eight communities in the Yukon Flats of Interior Alaska (Fig. 1). The Yukon Flats is located in the Upper Yukon River Drainage of Alaska within the boreal forest ecosystem. The Yukon Flats is characterized by a heterogeneous wetland basin with mixed forest including spruce (Picea spp.), birch (Betula spp.), aspen (Populus tremuloides), and willow (Salix spp.), bisected by the Yukon River and bounded to the north by the Brooks Range and the south by the White Mountains. The region has a continental subarctic climate, with seasonal extremes in temperature (January mean $=-23^{\circ} \mathrm{C}$, July mean $\left.=16^{\circ} \mathrm{C}\right)$ and length of daylight. Moose (Alces alces), caribou (Rangifer tarandus), salmon (Oncorhynchus spp.), and several species of waterfowl are the primary subsistence foods (Van Lanen et al. 2012). A variety of mammals are trapped mainly for fur including wolf (Canis lupus), marten (Martes americana), wolverine (Gulo gulo), lynx (Felis candadensis), beaver (Castor canadensis), and muskrat (Ondatra zibethicus). Black bears (Ursus americanus) and brown bears (U. arctos) also are present, but infrequently harvested for subsistence purposes.

Fig. 1. Locations of harvesters participating in a survey on the impacts of gasoline costs on subsistence activities in rural communities in the Upper Yukon Flats region of Alaska.

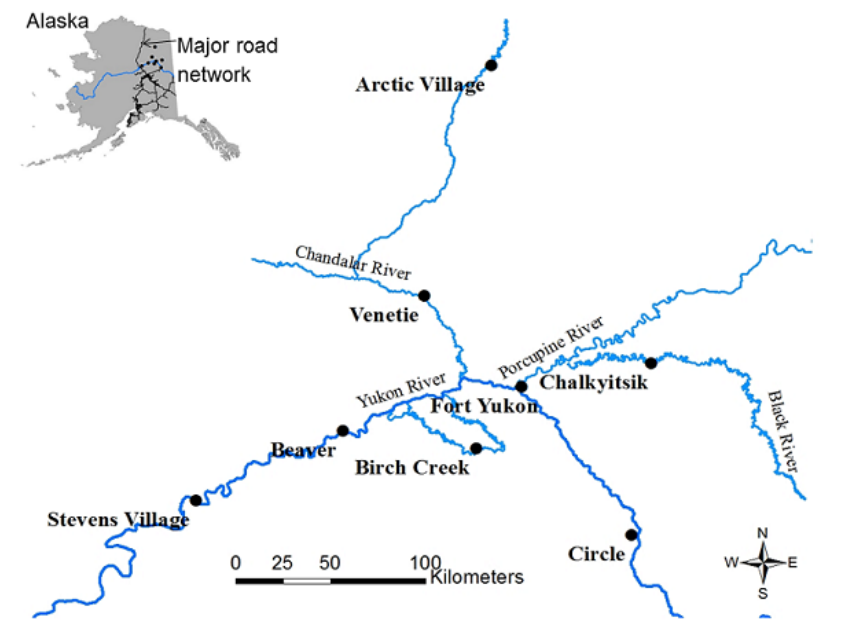

In 2011, the mean \pm SD population size across the eight communities was $162 \pm 183.3$ people, and mainly consisted of Alaska Natives ( $90 \%$ Athabascan Indians; Alaska Community Database 2012). Government agencies, tribal governments, and Native organizations are the primary employers in the region. According to the 2010 U.S. Census, the median \pm SD household income was $\$ 21,719 \pm \$ 11,619$, the mean \pm SD unemployment was $40 \% \pm 27.1 \%$, and the mean \pm SD percentage of individual residents with incomes below the poverty level was 35\% $\pm 19.1 \%$. These statistics illustrate the weakness of the cash economy and therefore the nutritional and cultural importance of a strong subsistence economy.

Of the eight communities studied, Circle is the only community that can be accessed by a passenger vehicle. A gravel road connects Circle to a major road and the closest urban center, Fairbanks, which is 249 road kilometers away. All communities except Arctic Village can be accessed by boat during the summer months, but only communities located on the Yukon River can receive fuel barges. With the exception of Circle, winter access to all communities is possible only by air or snowmobile. Therefore, one study community, Circle, receives fuel by truck; three, Stevens 
Village, Beaver, and Fort Yukon, receive fuel by barge; and the other four, Venetie, Arctic Village, Chalkyitsik, and Birch Creek, receive fuel by air. Annual data on gasoline prices were available back to 2005 for two study communities, Arctic Village and Circle, which represent the upper, i.e., air fuel delivery only, and lower, i.e., road fuel delivery available, fuel costs for our study communities. In Arctic Village, the price increased from $\$ 4.08$ per gallon $(\$ 1.08 / \mathrm{L})$ in 2005 to $\$ 10.00$ per gallon $(\$ 2.64 / \mathrm{L})$ in 2012. In Circle, the price increased from $\$ 3.30$ per gallon $(\$ 0.87 /$ L) in 2005 to $\$ 5.55$ per gallon $(\$ 1.47 / \mathrm{L})$ in 2012 (ADCCED 2012).

\section{METHODS}

Researchers from University of Alaska Fairbanks collaborated with the Council of Athabascan Tribal Governments Natural Resources Department to create a community survey to address the impact of changes in gasoline prices on subsistence activities such as hunting, fishing, trapping, and gathering. During spring 2012, staff from the Council of Athabascan Tribal Governments conducted face-to-face interviews with the most active and experienced subsistence harvesters in each community. These interview participants were chosen to facilitate the collection of in-depth practical knowledge and perceptions on the relationships between gasoline prices and subsistence over time. We worked with village tribal councils and organizations to assist with selection of participants. After initial participants were identified, we used peer selection and chain referral methods to locate additional candidates. For example, interview participants reviewed the list of harvesters included in the survey and suggested additional participants who were qualified to participate based on their subsistence harvest level and experience. The number of interview participants represented approximately $10 \%-20 \%$ of the total population in each community, but they harvested and shared between $50 \%$ and $75 \%$ of all subsistence resources used by their community. This conforms to the "superhunter" phenomenon common in many rural Alaska communities, where the majority of the community's wild food supply is provided by a minority of people (Andersen and Alexander 1992). Subsistence activities of interview participants were not representative of all individual residents in each community, but we assumed that participants' activities were representative of each community's subsistence system.

Interview participants were asked 22 multipart questions focused on identifying the relationship between gasoline costs and each of the following: (1) distance traveled to perform subsistence activities, (2) number of trips taken during a typical year to perform subsistence activities, and (3) price thresholds at which subsistence users began changing their activity or making sacrifices. Distance traveled was defined as the annual distance the interview participant would travel to perform subsistence activities. A trip was defined as any travel event from home for subsistence, e.g., caribou hunt, checking trap line, monitoring fish wheel. A sacrifice was defined as a serious decision such as putting off paying monthly bills or choosing not to buy basic essentials, and did not include altering the travel distance or the number of subsistence trips taken each year. To address change, we asked participants to consider how gasoline prices have affected subsistence activities during the last 10 years (2002-2012). We chose this time frame because we had data on gasoline prices for most years going back to 2005, and we assumed that interview participants could recall their subsistence patterns 10 years ago with reasonable accuracy. We had one openended question to collect responses on how hunters, fishers, and gatherers may be adapting their subsistence practices in response to changing gasoline prices beyond adjusting the distance they travel or the number of trips they take each year. We protected the anonymity of the respondents, and all methods and questions were approved by the University of Alaska Fairbanks Institutional Review Board (\#09-51) before the interview process.

We estimated means and medians (SD) for descriptive statistics. We used medians when data were asymmetrically distributed, i.e., when the ratio of skewness or kurtosis to its standard error was less than -2 or greater than +2 . We explored the differences in response to categorical explanatory variables on nonparametric response variables using the Kruskal-Wallis one-way analysis of variance test $(\alpha=0.05)$. We evaluated collinearity among explanatory variables using Pearson's correlation coefficient $(|\mathrm{r}|>0.50)$. Extreme outliers were eliminated before analysis. For normally distributed data, outliers were defined as any value beyond 3 SDs of the mean (Stevens 1992). For non-normally distributed data, outliers were defined as a value that fell more than three times the interquartile range below the first quartile or above the third quartile (Vaske 2008). We analyzed quantitative data using the computer program SPSS Statistics 19 (IBM Corporation, Somers, NY, USA). We transcribed responses to our open-ended question and used ATLAS computer software to query, code, and analyze qualitative data.

\section{RESULTS}

We interviewed 178 harvesters, who represented $14 \%$ of the total population of the eight communities. Harvesters used many modes to access subsistence resources depending on the season. Harvesters used snowmobiles and boats the most (Fig. 2). Participants harvested a median of $7( \pm 1.7 \mathrm{SD})$ different resources over the past 10 years. Firewood, waterfowl, and moose were harvested the most (Fig. 3).

Fig. 2. Ranking of different modes of access used based on frequency $(5=$ used the most, $1=$ used the least $)$ during the last 10 years (2002-2012) according to interviews with 178 subsistence harvesters in 8 rural communities in the Upper Yukon Flats region of Alaska.

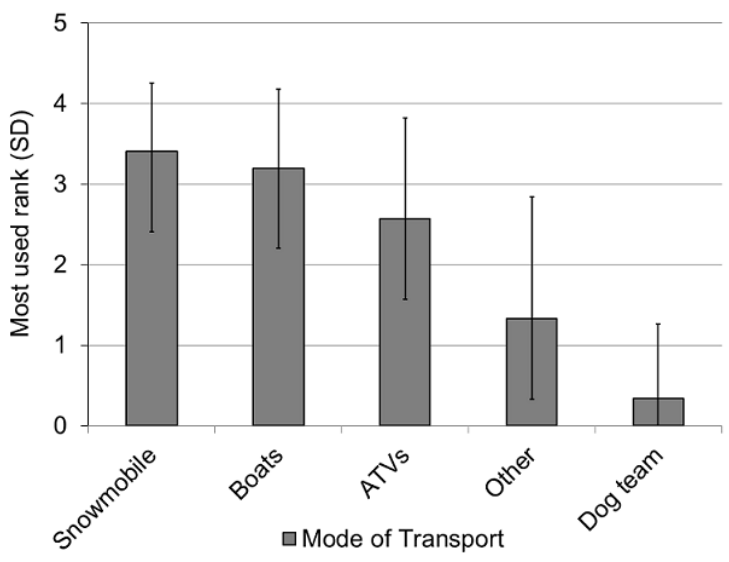


Table 1. Fuel cost impacts on subsistence activities during the last 10 years (2002-2012) according to interviews of 178 subsistence harvesters in 8 rural communities in the Upper Yukon Flats region of Alaska.

\begin{tabular}{|c|c|c|c|c|c|c|c|c|c|c|c|}
\hline \multirow[t]{2}{*}{$\begin{array}{l}\text { Community } \\
\text { (\# of } \\
\text { interviews) }\end{array}$} & \multicolumn{3}{|c|}{$\begin{array}{l}\text { In the last } 10 \text { years, how } \\
\text { have fuel prices affected } \\
\text { your subsistence } \\
\text { activities? }\end{array}$} & \multicolumn{2}{|c|}{$\begin{array}{l}\text { In the last } 10 \\
\text { years, have fuel } \\
\text { prices affected } \\
\text { how far you } \\
\text { would travel for } \\
\text { subsistence? }\end{array}$} & \multirow[t]{2}{*}{$\begin{array}{l}10 \text { years ago, } \\
\text { how far did } \\
\text { you travel for } \\
\text { subsistence? } \\
\text { (median km }{ }^{\dagger} \text {, } \\
\text { SD) }\end{array}$} & \multirow[t]{2}{*}{$\begin{array}{l}\text { Last year, how } \\
\text { far did you } \\
\text { travel for } \\
\text { subsistence? } \\
\text { (median km }{ }^{\dagger} \text {, } \\
\text { SD) }\end{array}$} & \multicolumn{2}{|c|}{$\begin{array}{l}\text { In the last } 10 \text { years, } \\
\text { have fuel prices } \\
\text { affected the number } \\
\text { of subsistence trips } \\
\text { taken? }\end{array}$} & \multirow[t]{2}{*}{$\begin{array}{l}10 \text { years ago, } \\
\text { how many } \\
\text { trips }^{\ddagger} \text { did you } \\
\text { take during the } \\
\text { year for } \\
\text { subsistence? } \\
\text { (median, SD) }\end{array}$} & \multirow[t]{2}{*}{$\begin{array}{l}\text { Last year, how } \\
\text { many trips }{ }^{\ddagger} \text { did } \\
\text { you take for } \\
\text { subsistence? } \\
\text { (median, SD) }\end{array}$} \\
\hline & A lot & Some & None & Yes & No & & & Yes & No & & \\
\hline $\begin{array}{l}\text { Arctic Village } \\
\text { (22) }\end{array}$ & $68 \%$ & $32 \%$ & $0 \%$ & $55 \%$ & $45 \%$ & $32(28)$ & 17 (29) & $77 \%$ & $23 \%$ & $300(473)$ & $150(189)$ \\
\hline $\begin{array}{l}\text { Beaver } \\
\text { (17) }\end{array}$ & $76 \%$ & $24 \%$ & $0 \%$ & $75 \%$ & $25 \%$ & $48(71)$ & $16(23)$ & $82 \%$ & $18 \%$ & $20(91)$ & $10(45)$ \\
\hline $\begin{array}{l}\text { Birch Creek } \\
\text { (3) }\end{array}$ & $100 \%$ & $0 \%$ & $0 \%$ & $100 \%$ & $0 \%$ & 97 (57) & $72(11)$ & $100 \%$ & $0 \%$ & $65(49)$ & $6(32)$ \\
\hline $\begin{array}{c}\text { Chalkyitsik } \\
\text { (16) }\end{array}$ & $63 \%$ & $31 \%$ & $6 \%$ & $67 \%$ & $33 \%$ & 322 (839) & $241(784)$ & $88 \%$ & $12 \%$ & $6(7)$ & $2(6)$ \\
\hline $\begin{array}{l}\text { Circle } \\
\text { (17) }\end{array}$ & $71 \%$ & $29 \%$ & $0 \%$ & $88 \%$ & $12 \%$ & 129 (1048) & $36(915)$ & $94 \%$ & $6 \%$ & $48(29)$ & 20 (19) \\
\hline $\begin{array}{l}\text { Fort Yukon } \\
\qquad(76)\end{array}$ & $84 \%$ & $16 \%$ & $0 \%$ & $91 \%$ & $9 \%$ & $322(435)$ & $80(260)$ & $93 \%$ & $7 \%$ & $100(282)$ & $50(84)$ \\
\hline $\begin{array}{l}\text { Stevens } \\
\text { Village } \\
\text { (3) }\end{array}$ & $100 \%$ & $0 \%$ & $0 \%$ & $100 \%$ & $0 \%$ & 80 (423) & $40(304)$ & $100 \%$ & $0 \%$ & $80(13)$ & 45 (19) \\
\hline $\begin{array}{l}\text { Venetie } \\
\text { (24) }\end{array}$ & $83 \%$ & $17 \%$ & $0 \%$ & $79 \%$ & $11 \%$ & $113(102)$ & $64(60)$ & $88 \%$ & $12 \%$ & 225 (129) & $50(78)$ \\
\hline $\begin{array}{l}\text { Total } \\
(178)\end{array}$ & $78 \%$ & $21 \%$ & $1 \%$ & $81 \%$ & $29 \%$ & $161(523)$ & 64 (407) & $89 \%$ & $11 \%$ & $100(289)$ & 25 (107) \\
\hline
\end{tabular}

This number represents the annual distance they would travel to perform subsistence activities.

* A trip is defined as any travel event from home for subsistence, e.g., caribou hunt, check trap line, or monitor fish wheel.

Fig. 3. (A) Percent of individual subsistence resources used by harvesters and (B) ranking of individual subsistence resources most impacted $(5=$ used the most, $1=$ used the least $)$ by gasoline prices during the last 10 years (2002-2012) according to interviews of 178 subsistence harvesters in 8 rural communities in the Upper Yukon Flats region of Alaska.

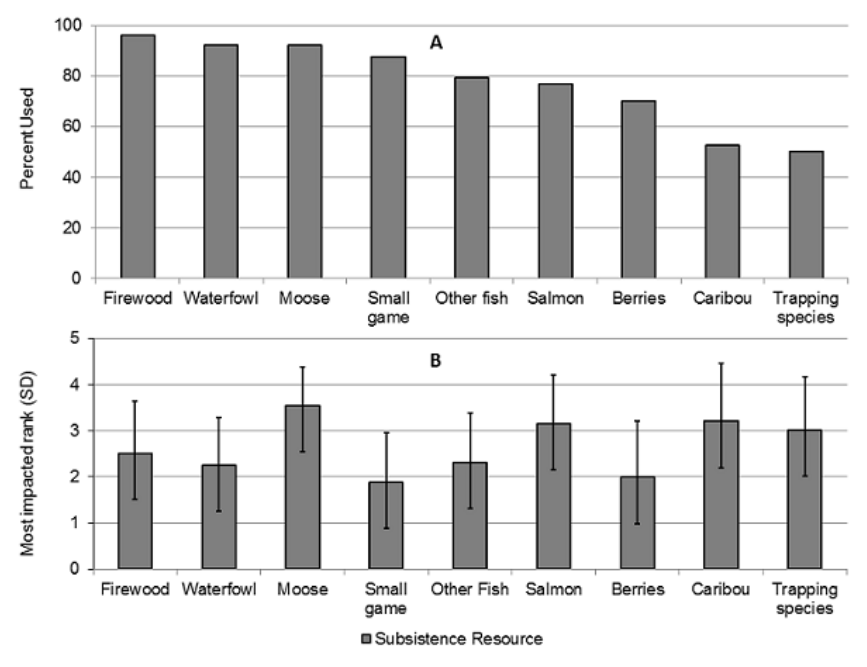

\section{Impacts of gasoline prices}

Gasoline prices have had a significant impact on subsistence activities across all communities. Only 1 of 178 people indicated that gasoline prices have not affected their ability to hunt, fish, trap, or gather subsistence resources, whereas $78 \%$ and $21 \%$ reporting that gasoline prices have affected them a lot and some, respectively (Table 1). In the last 10 years, $81 \%$ of people interviewed reported that they reduced the distance they traveled for subsistence and $89 \%$ reduced the number of trips they took for subsistence because of high gasoline costs (Table 1). In the last 10 years, the median distance traveled to perform subsistence activities decreased by $60 \%$, and the median annual number of trips taken to perform subsistence activities decreased by $75 \%$ (Table 1). Harvesters reported that moose, caribou, salmon, and trapping species were affected the most (Fig. 3).

We identified multicollinearity $(|r|>0.50)$ among survey responses to questions asking what the price of gasoline per gallon was when respondents (1) reduced the distance they would travel (median $\pm \mathrm{SD}=\$ 5.50[\$ 1.45 / \mathrm{L}] \pm \$ 1.55) ;(2)$ reduced the number of trips they would take each year (median $\pm \mathrm{SD}=\$ 6.00[\$ 1.58 / \mathrm{L}] \pm$ $\$ 1.46$ ); and (3) began making sacrifices, e.g., putting off paying monthly bills, to purchase gasoline for subsistence (median \pm SD $=\$ 6.00[\$ 1.58 / \mathrm{L}] \pm \$ 1.36)$. Therefore, we included only one of these explanatory variables (sacrifices, Table 2) in further analysis. Eighty-five percent of interview participants reported that they had to make sacrifices to purchase gasoline for subsistence. The median \pm SD amount that participants said they could spend each month on gasoline for subsistence without sacrifice was $\$ 200.00$ 
Table 2. Extent of sacrifices made and price thresholds related to purchasing fuel for subsistence during the last 10 years (2002-2012) according to interviews of 178 subsistence harvesters in 8 rural communities in the Upper Yukon Flats region of Alaska.

\begin{tabular}{|c|c|c|c|c|c|c|}
\hline \multirow[t]{2}{*}{$\begin{array}{c}\text { Community } \\
\text { (\# of interviews) }\end{array}$} & \multicolumn{2}{|c|}{$\begin{array}{l}\text { In the last } 10 \text { years, did you have to } \\
\text { make sacrifices }{ }^{\dagger} \text { so you could purchase } \\
\text { fuel for subsistence? }\end{array}$} & \multirow{2}{*}{$\begin{array}{l}\text { At what fuel price } \\
\text { did you make these } \\
\text { sacrifices }{ }^{\dagger} \text { ? (median } \\
\text { \$, SD) }\end{array}$} & \multirow{2}{*}{$\begin{array}{l}\text { How much can you spend } \\
\text { on fuel each month without } \\
\text { sacrifice }{ }^{\dagger} \text { ? } \\
\text { (median } \$, \text { SD) }\end{array}$} & \multicolumn{2}{|c|}{$\begin{array}{l}\text { Is the amount you spend on fuel } \\
\text { each month enough to meet } \\
\text { subsistence needs? }\end{array}$} \\
\hline & Yes & No & & & Yes & No \\
\hline $\begin{array}{l}\text { Arctic Village } \\
\text { (22) }\end{array}$ & $86 \%$ & $14 \%$ & $\$ 8.00(1.77)$ & $\$ 300(153.01)$ & $38 \%$ & $62 \%$ \\
\hline $\begin{array}{l}\text { Beaver } \\
\text { (17) }\end{array}$ & $65 \%$ & $35 \%$ & $\$ 6.00(0.98)$ & $\$ 200(256)$ & $53 \%$ & $47 \%$ \\
\hline $\begin{array}{l}\text { Birch Creek } \\
\text { (3) }\end{array}$ & $100 \%$ & $0 \%$ & $\$ 6.00(0.0)$ & NA $(n=2)$ & $0 \%$ & $100 \%$ \\
\hline $\begin{array}{c}\text { Chalkyitsik } \\
\text { (16) }\end{array}$ & $75 \%$ & $25 \%$ & $\$ 6.50(0.84)$ & $\$ 200.00(99.58)$ & $33 \%$ & $67 \%$ \\
\hline $\begin{array}{c}\text { Circle } \\
\text { (17) }\end{array}$ & $88 \%$ & $12 \%$ & $\$ 4.00(0.92)$ & $\$ 200.00(163.55)$ & $47 \%$ & $53 \%$ \\
\hline $\begin{array}{l}\text { Fort Yukon } \\
\text { (76) }\end{array}$ & $88 \%$ & $12 \%$ & $\$ 6.00(1.08)$ & $\$ 200.00(211.06)$ & 11 & $89 \%$ \\
\hline $\begin{array}{c}\text { Stevens Village } \\
\text { (3) }\end{array}$ & $100 \%$ & $0 \%$ & $\mathrm{NA}(n=0)$ & $\mathrm{NA}(n=1)$ & $0 \%$ & $100 \%$ \\
\hline $\begin{array}{l}\text { Venetie } \\
\text { (24) }\end{array}$ & $91 \%$ & $9 \%$ & $\$ 6.25(0.87)$ & $\$ 300.00(164.24)$ & $29 \%$ & $71 \%$ \\
\hline $\begin{array}{l}\text { All Communities } \\
\text { (178) }\end{array}$ & $85 \%$ & $15 \%$ & $\$ 6.00(1.36)$ & $\$ 200(190)$ & $26 \%$ & $74 \%$ \\
\hline
\end{tabular}

"Sacrifice" was defined as a serious decision such as putting off paying monthly bills or choosing not to buy basic essentials, and did not include altering the travel distance or the number of subsistence trips taken each year.

$\pm \$ 190.00$. The amount that could be spent on gasoline was not sufficient to meet subsistence needs according to $74 \%$ of interview participants (Table 2).

\section{Adaptation options}

For our open-ended question on how participants are adapting to gasoline prices beyond adjusting the distance they travel or the number of trips they take each year, participant responses were coded into six distinct categories that captured all responses. Most participants said that they are using more efficient modes of transportation $(69 \%)$, followed by sharing gasoline costs more with family and friends (37\%), conducting more multipurpose trips $(20 \%)$, spending more time at harvest areas during each trip $(6 \%)$, reducing the amount of subsistence foods they consume or abandoning harvest of certain resources (5\%), and seeking additional cash income just to cover gasoline for subsistence $(2 \%)$. Of the 122 participants reporting use of more efficient modes of transportation to adapt to gasoline price increases, the top strategy, based on frequency of response, was to use motors with better fuel efficiency $(60 \%)$, followed by walking more instead of using motorized vehicles $(57 \%)$, floating and paddling more instead of using motors $(16 \%)$, and trying to use dog teams more $(11 \%)$. Examples of the more efficient motors that participants reported included a transition from two-stroke to four-stroke engines, using more gasoline-efficient vehicles such as ATVs instead of boats with outboard motors, and switching to smaller snowmobiles and boats with better fuel efficiency. With regards to sharing gasoline costs, participants noted that the harvest now must be divided among more people, which required hunters to harvest more during each trip to meet everyone's needs. Lastly, participants explained that multipurpose trips usually meant that effort was put into harvesting several different types of resources during each trip, rather than concentrating on just one.

\section{DISCUSSION}

The significance and consistency of the impact of fuel prices on subsistence activity were striking across and within communities. Overall, we speculate that the absence of differences among participants with different subsistence patterns was likely because gasoline prices have already passed a threshold for all users, thus forcing all to change subsistence activities to some extent. Although no other studies are available for direct comparison of our findings, our results corroborate other reports addressing the relationship between gasoline prices and resource harvest. A survey of Alaska trappers found that fuel costs were the second most important factor, behind trapping conditions, affecting trapping effort (Schumacher 2010). A survey of fishers on the Yukon River found that fuel was consistently mentioned as the largest subsistence expense (Moncrieff 2007).

Harvesting of moose and caribou, salmon, and trapping species was thought to be impacted more by gasoline prices than harvesting firewood, small game, and berries. This finding likely relates to the distribution of large game and furbearers across the landscape. Historically and today, hunters in many communities travel long distances to reach caribou populations that are seasonally available (Caulfield 1983, Van Lanen et al. 2012). Low densities of moose in the Yukon Flats (Lake et al. 2013) also may require more travel across the landscape to encounter a sufficient number of moose. Salmon harvest requires many trips relative to other resources, because nets and fish wheels must be visited frequently, e.g., daily to weekly, to collect fresh catch and to 
maintain equipment vulnerable to damage from debris floating in the river. Traplines may be several hundred miles long and also must be checked regularly, e.g., weekly, to avoid damage to furs by other animals and ensure trap sets are functional (Caulfield 1983, Van Lanen et al. 2012). Other resources that were reported to be minimally affected by fuel prices, such as berries, are more ubiquitous across the landscape and near communities. They may require shorter travel distances for harvest, or they may be opportunistically harvested while residents are out on the landscape for other reasons. For example, seasonal densities of waterfowl throughout the Yukon Flats are high with vast distribution, so residents are able to travel a short distance to highquality harvest areas.

Because gasoline prices are largely out of local control and driven by global markets, adaptation may be a more feasible option than mitigation. The majority of participants reported that they have begun changing their subsistence strategies in response to rising gasoline prices. New methods identified during interviews continued to mainly rely on gasoline-powered modes of transportation, but each altered strategy involved an attempt to spend less on gasoline for subsistence. Several adaptation strategies resulted in either altered social dynamics, e.g., more sharing of costs, or changes in the structure of each subsistence outing, e.g., staying out longer and attempting to harvest multiple resources during each trip. We speculate that these modifications have affected fundamental components of the subsistence system such as food sharing and harvest success. We suggest that future research should evaluate these important interactions.

Some of adaption strategies such as walking, paddling, and dog teams severed the connection between fossil fuels and subsistence practices. However, returning to the use of dogs as the primary mode of access to local resources is unrealistic. Dogs were a practical alternative when they were used for everything, e.g., subsistence, hauling water, hauling wood, and traveling to adjacent communities (Andersen 1992). With a decline in salmon in the Yukon River, less food is available to feed large dog teams, and high shipping costs serve as a barrier to importing commercial dog food (Busher et al. 2009). Today, dog teams in rural areas primarily are raised for competitive racing or a recreational activity, rather than for utility and daily tasks. The dogs seen in rural areas are built for speed and endurance, instead of for pulling freight such as firewood. Overall, it may be idealistic and naive to think that rural residents can return to a subsistence lifestyle without motorized vehicles. These vehicles became popular because they allowed people to travel farther and faster (Schroeder et al. 1987), which freed up time for other commitments such as wage employment and regular attendance of residents' children in public schools. The latter was one of the primary reasons why rural societies formed centralized and permanent communities, and became more sedentary (Barnhardt 2001). Historically, these societies relocated seasonally to temporary camps, e.g., fish camps, in the immediate proximity of the resource being harvested (Caulfield 1983, Van Lanen et al. 2012). The imposition of the Alaska Native Claims Settlement Act created many policies that would have to change to accommodate a return to a seminomadic way of life. Further, we are not aware of any recent data or ethnographies that suggest rural communities want to or can return to that lifestyle under the current evolution of culture. A better option may be to shift attention toward modes of transportation that could be powered by renewable local resources such as biomass, wind, and solar energy. For example, several universities have created electric snowmobiles that rival the performance of those that run on gasoline (Golub et al. 2009). In addition, major manufacturers are now offering electric versions of both ATVs and utility task vehicles. With the current manufacturer's suggested retail price of $\$ 17,000$ for an electric snowmobile, this technology will still be unaffordable for rural consumers in the foreseeable future.

We can speculate on how reduced subsistence activity may be affecting local people and local resources. For example, reduced travel distance condenses harvest effort into a smaller area around communities. Potentially, this could lead to overexploitation of resources close to communities or reduced harvest success, i.e., catch per unit effort, in these areas. From a cultural perspective, the most negative consequence of reduced harvest and financial limitations imposed by gasoline prices is a decline in reliance on local resources or abandonment of a subsistence lifestyle. Our results indicate that this has not occurred among participants, given that only $5 \%$ of participants reported that they have adapted to rising gasoline prices by reducing reliance on local resources or abandoning a subsistence lifestyle. However, across rural Alaska, there has been a decline in the harvest and use of subsistence resources (Wolfe 2000, Fall 2012), and less reliance on subsistence has been reported to reduce the physical and cultural health of rural communities (Lambden et al. 2007, Smith et al. 2009). A subsistence lifestyle requires physical activity, and subsistence resources such as salmon and moose are a relatively healthy alternative to the packaged food found in rural grocery stores. For instance, a reduction in the percentage of people practicing a subsistence lifestyle is thought to be related to the acceleration in rates of obesity and chronic disease in rural Alaska (Mohatt et al. 2007).

Although our results suggest that gasoline prices have clearly had an impact, subsistence researchers, managers, and policy makers must be aware that subsistence practices are part of a complex, coupled social-ecological system, and several other factors such as regulatory policy influence levels of subsistence activity. These factors may amplify the effects that gasoline prices are having on subsistence activities. For example, household costs for heating fuel and electricity take a significant part of household income in Interior Alaska (Saylor and Haley 2007). As costs of other basic essentials such as groceries increase, the amount that can be allocated toward gasoline each month (median $=\$ 200)$ may continue to decline even if the gasoline price remains constant. The close connection between gasoline prices and other household expenses warrants research into the interaction of social, economic, and ecological factors to better understand the relative impact of rising gasoline costs on subsistence opportunities, and to help highlight adaptation or mitigation options. Other commitments, such as wage employment, may reduce the amount of time that people can practice subsistence (Moerlein and Carothers 2012). Cultural changes, such as assimilation to a consumer cash economy and engagement in electronic media and modern conveniences, also may influence overall desire of people to practice a subsistence lifestyle, especially among younger generations (Condon et al. 1995). Ecologically, the distribution and abundance of subsistence resources could be influencing when, where, and how people 
practice subsistence (Brinkman et al. 2009, 2013). In addition, changes in resource dynamics may cause a change in subsistence regulations, which could further limit subsistence activity. For example, dismal king salmon runs on the Yukon River in recent years have resulted in several closures to the fishery (Loring et al. 2011). Therefore, activity levels among subsistence users that concentrate their efforts on king salmon may be as limited by regulations as by gasoline costs. However, it is unlikely that resource dynamics and regulations are driving the changes we identified in subsistence activity. Participants reported that the harvest of all species has been impacted by gasoline costs, and the availability of many species such as moose, waterfowl, and caribou has not shown a statistically discernable decline during the last 10 years (Lenart 2009, Lake et al. 2013).

Although additional data are needed to estimate the effects of confounding factors, gasoline prices are clearly having a major impact on subsistence. If we only considered responses from the 34 harvesters (19\%) who said gasoline prices haven't affected the distance they traveled for subsistence, we found that 10 harvesters still reported a median \pm SD decrease in distance traveled of $-27 \%$ $\pm 1.23 \%$ during the last 10 years. Assuming factors other than gasoline, e.g., ecological and cultural, were responsible for that decrease, then we conclude that the decline in distance traveled because of gasoline was approximately 33\%: the $60 \%$ mean percent decline of harvesters affected by gas prices minus the $27 \%$ mean percent decline of harvesters unaffected by gas prices. Ideally, future research that simultaneously collects real-time data on gasoline prices, household gasoline consumption specifically for subsistence, percentage of household income devoted to gasoline, and household subsistence activity may help isolate the individual impact of gasoline costs on subsistence among all the other stresses, e.g., climate change, heating fuel costs, and grocery prices, that rural communities are coping with. Currently, gasoline consumption data are available for one community for a four-year period (2008-2012; Crowley Petroleum Distribution, Inc., Fairbanks, Alaska, Unpublished data).

Subsistence in the Arctic now relies on cash for purchasing, maintaining, and fueling motorized transportation. However, the challenges that subsistence systems confront are not unique. In general, any society that has become reliant on a narrow range of resources to sustain livelihoods may experience social and economic stress (Adger 2000). For example, agricultural systems have become more specialized, mechanized, and globally connected (Bowman and Zilberman 2013). Rural farmers who are unable to adapt to, compete with, or access global markets are facing increased vulnerability (Leichenko and O'Brien 2002). The tight linkage between dependence on petroleum, cash, and external goods under control of international markets has influenced the resilience of many social-ecological systems. The weakened resilience in rural Alaska is acutely obvious because many communities were almost completely isolated and selfsufficient less than a century ago. In general, we speculate the effects on rural systems have been more pronounced because actors within those systems may have fewer options to engage in cash economies. Our finding that only $2 \%$ of interview participants sought additional wage employment in response to rising fuel prices supports our speculation.
To maintain the desirable attributes of a subsistence lifestyle, Arctic societies will probably need to reconfigure interactions with technology and the local environment in a way that complements a culture of self-reliance. Logically, local communities and individuals will need to decide how this reconfiguration occurs. At an institutional level, e.g., government agencies, efforts are needed to sustain subsistence opportunities while communities self-organize and experiment with adaptive processes. Institutional actions may include creative and flexible liberalizations of harvest regulations or more attention to interacting stressors, e.g., climate change, and feedbacks serving as barriers to productive change. A positive feedback loop with obviously negative implications is how the inability to buy gasoline to get firewood and harvest wild foods requires more dependency on diesel fuel for heating and groceries. More money allocated for heating fuel and groceries reduces funds for gasoline. Despite recent hardships, the willingness to continue a subsistence lifestyle and break undesirable cycles was very evident. Nearly all harvesters continued to practice a subsistence lifestyle and were experimenting with ways to reduce vulnerability. Harvester responses showed that options exist that may enhance social resilience. Ultimately, continued collaboration with communities on both the effectiveness of adaptive strategies and ways to spread promising innovations will be beneficial to high-latitude communities and other societies facing adversity because of a reliance on unaffordable fuel moving on an unfavorable trajectory.

\section{Responses to this article can be read online at: http://www.ecologyandsociety.org/issues/responses. $\mathrm{php} / 6861$}

\begin{abstract}
Acknowledgments:
We thank all the harvesters who participated in this study and shared their time and knowledge. We thank T. Chapin for helpful comments on earlier versions of this article. Funding was provided by the Resilience and Adaptation Program (Integrative Graduate Education and Research Traineeship, National Science Foundation [NSF] 0654441), the Bonanza Creek Long Term Ecological Research Site (NSF 0423442), the International Polar Year (NSF 0732758), the Institute of Arctic Biology, and the Scenarios Network for Alaska and Arctic Planning at the University of Alaska Fairbanks.
\end{abstract}

\section{LITERATURE CITED}

Adger, W. N. 2000. Social and ecological resilience: are they related? Progress in Human Geography 24:347-364. http://dx.doi. org/10.1191/030913200701540465

Alaska Community Database. 2014. Community information summaries. Division of Community and Regional Affairs, Alaska Department of Commerce, Community, and Economic Development, Anchorage, Alaska, USA.

Alaska Department of Commerce, Community, and Economic Development (ADCCED). 2005. Current community conditions: fuel prices across Alaska. Research and Analysis Section, Division 
of Community and Regional Affairs, Alaska Department of Commerce, Community, and Economic Development, Anchorage, Alaska, USA.

Alaska Department of Commerce, Community, and Economic Development (ADCCED). 2012. Current community conditions: Alaska fuel price report. Research and Analysis Section, Division of Community and Regional Affairs, Alaska Department of Commerce, Community, and Economic Development, Anchorage, Alaska, USA.

Andersen, D. B. 1992. The use of dog teams and the use of subsistence-caught fish for feeding sled dogs in the Yukon River Drainage, Alaska. Technical Paper No. 210. Division of Subsistence, Alaska Department of Fish and Game, Juneau, Alaska, USA.

Andersen, D. B., and C. L. Alexander. 1992. Subsistence hunting patterns and compliance with moose harvest reporting requirements in rural interior Alaska. Technical Paper No. 215. Division of Subsistence, Alaska Department of Fish and Game, Juneau, Alaska, USA.

Barnhardt, C. 2001. A history of schooling for Alaska Native people. Journal of American Indian Education 4:1-30.

Berkes, F., and C. Folke, editors. 1998. Linking social and ecological systems: management practices and social mechanisms for building resilience. Cambridge University Press, Cambridge, UK.

Bowman, M. S., and D. Zilberman. 2013. Economic factors affecting diversified farming systems. Ecology and Society 18(1): 33. http://dx.doi.org/10.5751/ES-05574-180133

Brinkman, T. J., F. S. Chapin III, G. P. Kofinas, and D. K. Person. 2009. Linking hunter knowledge with forest change to understand changing deer harvest opportunities in intensively logged landscapes. Ecology and Society 14(1): 36. [online] URL: http:// www.ecologyandsociety.org/vol14/iss1/art36/

Brinkman, T. J., G. Kofinas, W. D. Hansen, F. S. Chapin III, and S. Rupp. 2013. A new framework to manage hunting: why we should shift focus from abundance to availability. Wildlife Professional 7(3):38-43.

Busher, W. H., T. Hamazaki, and D. M. Jallen. 2009. Subsistence and personal use salmon harvests in the Alaska portion of the Yukon River Drainage, 2008. Fishery Data Series No. 09-73. Alaska Department of Fish and Game, Anchorage, Alaska, USA.

Caulfield, R. 1983. Subsistence land use in Upper YukonPorcupine communities, Alaska. Technical Paper No. 16. Division of Subsistence, Alaska Department of Fish and Game, Fairbanks, Alaska, USA.

Chapin, F. S., III, G. P. Kofinas, and C. Folke, editors. 2009. Principles of ecosystem stewardship: resilience-based natural resource management in a changing world. Springer, New York, New York, USA.

Condon, R. G., P. Collings, and G. Wenzel. 1995. The best part of life: subsistence hunting, ethnicity, and economic adaptation among young-adult Inuit males. Arctic 48:31-46. http://dx.doi. org/10.14430/arctic1222
Fall, J. A. 2012. Subsistence in Alaska: a year 2010 update. Division of Subsistence, Alaska Department of Fish and Game, Anchorage, Alaska, USA.

Folke, C., S. Carpenter, T. Elmqvist, L. Gunderson, C. S. Holling, and B. Walker. 2002. Resilience and sustainable development: building adaptive capacity in a world of transformations. Ambio 31(5):437-440.

Francis, K. E. 1969. Decline of the dogsled in villages of arctic Alaska: a preliminary discussion. Association of Pacific Coast Geographers Yearbook 31:69-78. http://dx.doi.org/10.1353/ pcg. 1969.0008

Golub, M., M. Nelson, P. Morris, M. Deighton, M. Van Atta, and L. Stowell. 2009. Design and construction of an affordable zero-emissions snowmobile. CSC Tech Paper. SAE International, Warrendale, Pennsylvania, USA. [online] URL: http://www. mtukrc.org/download/uaf/uaf ze design paper 2009.pdf

Hall, E. S. Jr. 1971. The "iron dog" in Northern Alaska. Anthropologica 13:237-254. http://dx.doi.org/10.2307/25604852

Heltberg, R., N. Hossain, A. Reva, and C. Turk. 2013. Coping and resilience during the food, fuel, and financial crises. Journal of Development Studies 49:705-718. http://dx.doi. org/10.1080/00220388.2012.746668

Kinzig, A. P., P. Ryan, M. Etienne, H. Allison, T. Elmqvist, and B. H. Walker. 2006. Resilience and regime shifts: assessing cascading effects. Ecology and Society 11(1): 20. [online] URL: http://www.ecologyandsociety.org/vol11/iss1/art20/

Kofinas, G. P. 1998. The cost of power sharing: community involvement in Canadian porcupine caribou co-management. Dissertation. University of British Columbia, Vancouver, British Columbia, Canada.

Kofinas, G. P., F. S. Chapin III, S. BurnSilver, J. I. Schmidt, N. L. Fresco, K. Kielland, S. Martin, A. Springsteen, and T. S. Rupp. 2010. Resilience of Athabascan subsistence systems to interior Alaska's changing climate. Canadian Journal of Forest Research 40:1347-1359. http://dx.doi.org/10.1139/X10-108

Lake, B. C., M. R. Bertram, N. Guldager, J. R. Caikoski, and R. O. Stephenson. 2013. Wolf kill rates across winter in a low-density moose system in Alaska. Journal of Wildlife Management 77:1512-1522. http://dx.doi.org/10.1002/jwmg.603

Lambden, J., O. Receveur, and H. V. Kuhnlein. 2007. Traditional food attributes must be included in studies of food security in the Canadian Arctic. International Journal of Circumpolar Health 66 (4):308-319. http://dx.doi.org/10.3402/ijch.v66i4.18272

Leichenko, R. M., and K. L. O'Brien. 2002. The dynamics of rural vulnerability to global change: the case of southern Africa. Mitigation and Adaptation Strategies for Global Change 7:1-18. http://dx.doi.org/10.1023/A:1015860421954

Lenart, E. A. 2009. Units 26B and 26C caribou. Pages 299-325 in P. Harper, editor. Caribou management report of survey and inventory activities 1 July 2006-30 June 2008. Project 3.0. Alaska Department of Fish and Game, Juneau, Alaska, USA.

Loring, P. A., S. C. Gerlach, D. E. Atkinson, and M. S. Murray. 2011. Ways to help and ways to hinder: governance for effective 
adaptation to an uncertain climate. Arctic 64(1):73-88. http://dx. doi.org/10.14430/arctic4081

McNeeley, S. M., and M. D. Shulski. 2011. Anatomy of a closing window: vulnerability to changing seasonality in Interior Alaska. Global Environmental Change 21(2):464-473. http://dx.doi. org/10.1016/j.gloenvcha.2011.02.003

Moerlein, K. J., and C. Carothers. 2012. Total environment of change: impacts of climate change and social transitions on subsistence fisheries in Northwest Alaska. Ecology and Society 17(1): 10. http://dx.doi.org/10.5751/ES-04543-170110

Mohatt, G. V., R. Plaetke, J. Klejka, B. Luick, C. Lardon, A. Bersamin, S. Hopkins, M. Dondanville, J. Herron, B. Boyer, and the CANHR Research team. 2007. The Center for Alaska Native Health Research Study: A community-based participatory research study of obesity and chronic disease-related protective and risk factors. International Journal of Circumpolar Health 66 (1):8-18. http://dx.doi.org/10.3402/ijch.v66i1.18219

Moncrieff, C. F. 2007. Traditional ecological knowledge of customary trade of subsistence-harvested fish on the Yukon River. U.S Fish and Wildlife Service, Office of Subsistence Management, Fisheries Resource Monitoring Program. 2007 Final Report (Study No. 04-265). Yukon River Drainage Fisheries Association, Anchorage, Alaska, USA.

Nelson, J. L., E. S. Zavaleta, and F. S. Chapin III. 2008. Boreal fire effects on subsistence resources in Alaska and adjacent Canada. Ecosystems 11:156-171. http://dx.doi.org/10.1007/ $\underline{\mathrm{s} 10021-007-9114-\mathrm{Z}}$

Osburn, W. S. Jr. 1974. The snowmobile in Eskimo culture. Pages 911-913 in J. D. Ives and R. G. Barry, editors. Arctic and alpine environments. Harper and Row, New York, New York, USA.

Saylor, B., and S. Haley. 2007. Effects of rising utility costs on household budgets, 2000-2006. Institute of Social and Economic Research, University of Alaska, Anchorage, Alaska, USA. [online] URL: http://www.iser.uaa.alaska.edu/Publications/ risingutilitycosts final.pdf

Schroeder, R. F., D. B. Andersen, R. Bosworth, J. M. Morris, and J. M. Wright. 1987. Subsistence in Alaska: Arctic, Interior, Southcentral, Southwest, and Western regional summaries. Technical Paper No. 150. Division of Subsistence, Alaska Department of Fish and Game, Juneau, Alaska, USA.

Schumacher, T. 2010. Trapper questionnaire. Alaska Department of Fish and Game Division of Wildlife Conservation, Juneau, Alaska, USA.

Smit, B., and J. Wandel. 2006. Adaptation, adaptive capacity and vulnerability. Global Environmental Change 16(3):282-292. http:// dx.doi.org/10.1016/j.gloenvcha.2006.03.008

Smith, J., B. Saylor, P. Easton, and D. Wiedman. 2009. Measurable benefits of traditional food customs in the lives of rural and urban Alaska Inupiaq elders. Alaska Journal of Anthropology 7 (1):87-97.

Stevens, J. 1992. Applied multivariate statistics for the social sciences. Second edition. Lawrence Erlbaum Associates, Hillsdale, New Jersey, USA.
Szymoniak, N., F. Ginny, A. Villalobos-Melendez, C. Justine, and M. Smith. 2010. Components of Alaska fuel costs: an analysis of the market factors and characteristics that influence rural fuel prices. Prepared for the Alaska State Legislature, Senate Finance Committee. Institute of Social and Economic Research, University of Alaska Anchorage, Anchorage, Alaska, USA.

U.S. Energy Information Administration. 2012. Petroleum \& other liquids: gasoline and diesel fuel update. Department of Energy, Washington D.C., USA. [online] URL: http://www.eia. gov/petroleum/gasdiesel/

Van Lanen, J. M., C. Stevens, C. L. Brown, K. B. Maracle, and D. S. Koster. 2012. Subsistence land mammal harvests and uses, Yukon Flats, Alaska: 2008-2010 harvest report and ethnographic update. Technical Paper No. 377. Division of Subsistence, Alaska Department of Fish and Game, Anchorage, Alaska, USA.

Vaske, J. J. 2008. Survey research and analysis: applications in parks, recreation, and human dimensions. Venture Publishing, State College, Pennsylvania, USA.

Wolfe, R. J. 2000. Subsistence in Alaska: a year 2000 update. Division of Subsistence, Alaska Department of Fish and Game, Anchorage, Alaska, USA. 